\title{
Glycation research in amino acids: a place to call home
}

\author{
Naila Rabbani $\cdot$ Paul J. Thornalley
}

Published online: 28 October 2010

(C) Springer-Verlag 2010

\begin{abstract}
This is an introduction to a collection of review articles by leading investigators in the field of protein glycation research, see following articles in this issue. With this we launch a section of this journal now established for presentation of research results, reviews and commentaries on protein glycation and related topics. Glycation is the spontaneous, non-enzymatic reaction of protein with saccharides and saccharide derivatives. Although studied in the modern scientific era for over 100 years, its importance in the biology, medicine, food and nutrition, pharmacology and toxicology, and technological processing remains intriguingly undisclosed. In this section of amino acids, research on glycation is a qualifier for publication. Glycation research now has a place to call home.
\end{abstract}

\section{Glycation: nomenclature and classification}

In 1985 the Nomenclature Committee of International Union of Biochemistry and the International Union of Pure and Applied Chemistry recommended the term glycation for "all reactions that link a sugar to a protein or a peptide, whether or not catalysed by an enzyme"-drafted by Sharon (1986). In a subsequent review in 1993, Lis and Sharon distinguished between enzymatic modification of proteins by saccharides in processes of protein glycosylation forming glycoproteins and non-enzymatic modification of proteins by saccharides in processes of protein

N. Rabbani $(\bowtie) \cdot$ P. J. Thornalley

Clinical Sciences Research Institute, Warwick Medical School,

University of Warwick, University Hospital, Clifford Bridge

Road, Coventry CV2 2DX, UK

e-mail: N.Rabbani@warwick.ac.uk glycation forming glycated proteins (Lis and Sharon 1993). This eventually led to selective use of the term glycation for non-enzymatic modification of proteins by saccharides such that it is now accepted nomenclature. In older scientific literature, one of the most prominent glycated proteins, haemoglobin, has been called glycosylated haemoglobin, non-enzymatic glycosylated haemoglobin, glycohaemoglobin, glucosylated haemoglobin and other variants.

Protein glycation involves the non-enzymatic attachment of a reducing sugar or sugar derivative to a protein. The term "reducing" related to the classical activity of saccharides with solution species with free aldehyde or ketone groups which reduced Benedict's solution (Benedict 1909). Glycation is not available to non-reducing oligosaccharides where aldehyde or ketone groups of component monosaccharides have been converted to ketal and acetal groups of glycosidic bonds-such as in sucrose (table sugar). In its earliest development, protein glycation was thought to be restricted to modification of amino groups of lysine residue side chains and N-terminal amino acid residues. In more recent times, glycation of arginine residues by dicarbonyl metabolites has emerged as a major feature of protein glycation in physiological systems. There is also involvement of cysteine residues.

Glycation of proteins occurs by a complex series of sequential and parallel reactions called collectively the Maillard reaction-named after the leading pioneer of glycation research, Louis Camille Maillard (1878-1936). Many different adducts may be formed-some of which are fluorescent and coloured "browning pigments". In the physiological setting, one of the important saccharides participating in glycation of mammalian metabolism is glucose, and some of the most important saccharide derivatives are the reactive dicarbonyl metabolites such as methylglyoxal (MG). 
Historically, glycation of lysyl side chain and N-terminal amino groups by glucose was the major glycation process studied in the glycation of proteins. This has given rise to the classification of early and advanced glycation processes. Glucose reacts with amino groups to initially form a glycosylamine which dehydrates to form a Schiff's base. The Schiff's base undergoes an Amadori rearrangement to form $N$-(1-deoxy-D-fructos-1-yl)amino acids or fructosamine (Hodge 1955). Glycation of proteins by glucose to the fructosamine stage has been classified as early glycation. Glycosylamine, Schiff's base and fructosamines are considered to be early stage glycation adducts. In later stage reactions fructosamine degrades to many stable end-stage adducts called advanced glycation endproducts (AGEs)-Fig. 1a. This is a broader definition of AGEs than originally given by Cerami as "brown fluorescent pigments which crosslink proteins" (Cerami 1986). Inconsistencies in the application of this classification and nomenclature have recently arisen because glucose may degrade when unattached to protein to form reactive $\alpha$-oxoaldehydes. $\alpha$-Oxoaldehydes are potent glycating agents and react with proteins to form AGEs directly. The Schiff's base adduct may also degrade via non-Amadori rearrangement reaction pathways to $\alpha$-oxoaldehydes which also leads to the formation of AGEs. The latter are also formed by the direct modification of proteins by $\alpha$-oxoaldehydes
Fig. 1 Protein glycation. a Early glycation and sources of advanced glycation endproducts (AGEs). b Some important glycating agents.

c Classification of protein glycation adduct residues, peptides and free adducts. The $12 \mathrm{kDa}$ discrimination for protein glycation adduct residues and peptides is empirical and relates to the pore size of ultrafiltration membrane used in separation a

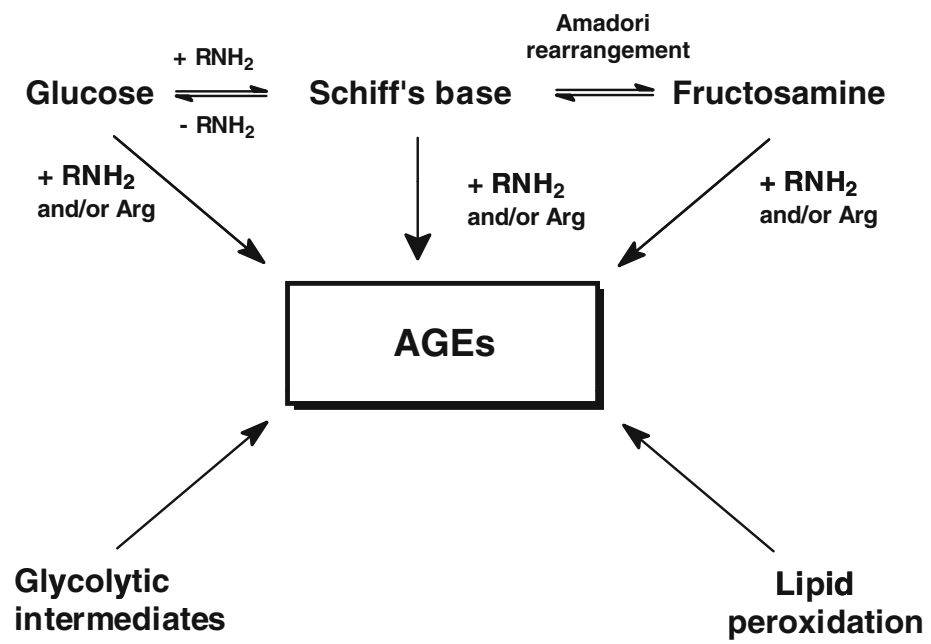

b

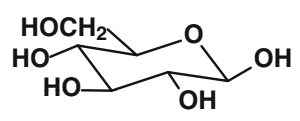<smiles>O=CC=O</smiles><smiles>CC(=O)C=O</smiles><smiles>O=CC(=O)CC(O)C(O)CO</smiles>

Glucose

Glyoxal

Methylglyoxal c

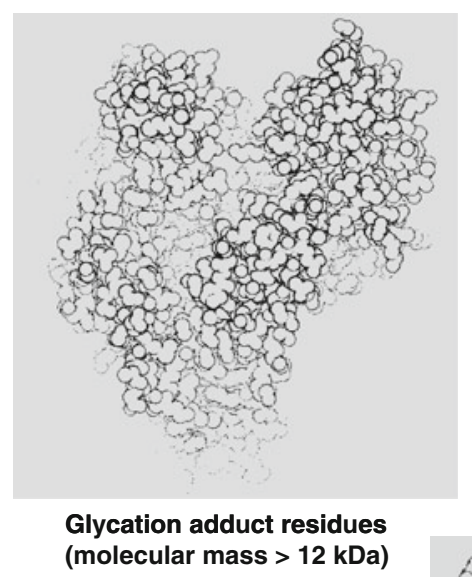

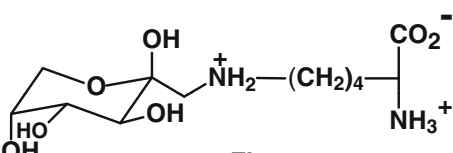

FL<smiles>CCCCNC1=NC(=O)C(C)N1</smiles>

$\underset{\mathrm{NH}_{3}+}{\mathrm{CO}_{2}{ }^{-}}\left(\mathrm{CH}_{2}\right)_{4}-\mathrm{N}^{+} \mathrm{H}_{2} \mathrm{CH}_{2} \mathrm{CO}_{2}{ }^{-}$

Glycation free adducts (molecular mass < 0.5 kDa) 
produced by the degradation of glycolytic intermediates and lipid peroxidation. Important $\alpha$-oxoaldehyde or dicarbonyl glycating agents are glyoxal, MG, and 3-deoxyglucosone (3-DG)_Fig. 1b. Therefore, AGEs may be formed in glycation by glucose in pre- and post-Amadori product reactions, and indeed in processes where an Amadori product is not a precursor. AGEs may be formed in both the early and late stages of glycation processes. The term "advanced glycation endproducts" is a misnomer in that AGEs are formed in both early and later, advanced stages of the Maillard reaction. The concept of early and advanced glycation adducts is, however, simple and the nomenclature of fructosamine and AGEs is convenient, widely used, understood and accepted. Molecular structures of fructosamines and some common AGEs are given in Fig. 2.

Further classification of AGEs has been made to relate to the mechanism of AGE formation. "Glycoxidation" is a term in general use for glycation processes in which oxidation is involved and the AGEs formed thereby have been called "glycoxidation products" (Baynes 1991). The AGEs pentosidine and CML are examples of glycoxidation products. Where aldehyde substrates of glycation are formed by lipid peroxidation, the endstage adducts have been called advanced lipoxidation adducts (ALEs). CML is also an ALE as it may be formed from glyoxal generated from lipid peroxidation (Fu et al. 1996) Other classifications were devised but currently are not in widespread use (Baynes and Thorpe 2000)-Fig. 1.

Glycation adducts of proteins are formed by modification of amino acid residues of proteins with monosaccharides or saccharide derivatives. They are appropriately called, therefore, glycation adduct residues-such as the fructosamine residues of glycated haemoglobin and AGE residues of AGE-modified proteins. Glycated proteins
Fig. 2 Molecular structures of glycation adduct residues. a Early glycation adducts formed by glycation with glucose: fructosamines. $R$ indicates the amino acid side chain. b-f Advanced glycation endproducts.

b Hydroimidazolones.

c Monolysine adducts.

d Imidazolium and other crosslinks. e Fluorophores. f Other structures. The peptide linkage is shown cut away for clarity. For the corresponding free adducts at physiological $\mathrm{pH}$, the $\mathrm{N}$-terminal amino group is protonated $-\mathrm{NH}_{3}{ }^{+}$and the C-terminal carbonyl is a carboxylate $-\mathrm{CO}_{2}^{-}$moiety. Ionisation status is given for the major solution form at $\mathrm{pH} 7.4$ a

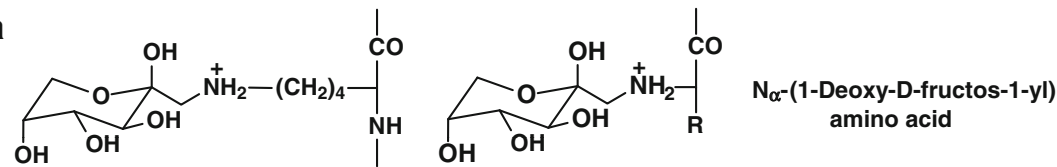

b

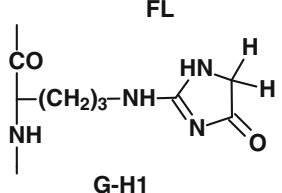

G-H1

C

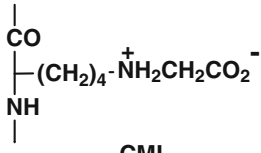

CML

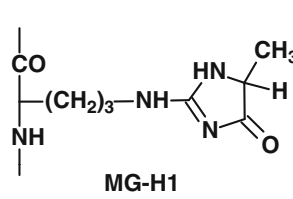<smiles>CNC(C)(C)C(C)NCC1=NC(=O)C(CCO)N1</smiles>

d

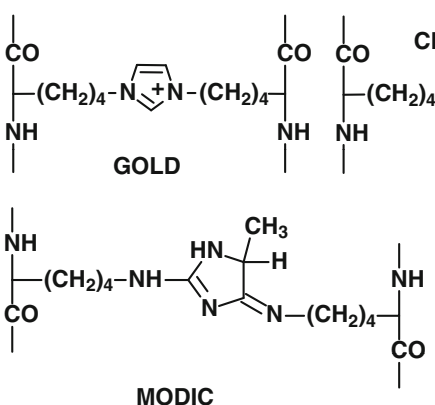

MODIC

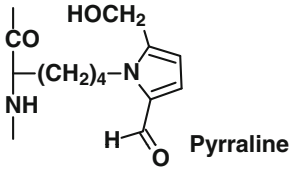

CEL
$(\mathrm{CHOH})_{2} \mathrm{CH}_{2} \mathrm{OH}$<smiles></smiles><smiles>CNC(C)(C)C(=O)O</smiles><smiles>CNC1=NC2C[C@H](O)[C@H](O)C[NH+](C)C2=N1</smiles>
Glucosepane

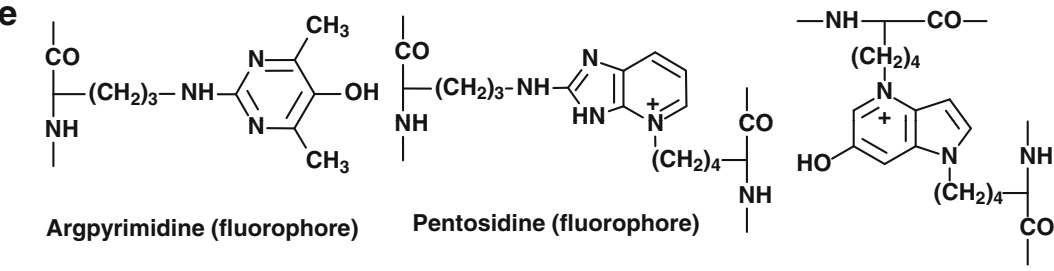

f

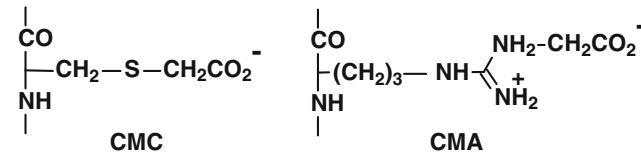


undergo proteolysis during digestion of ingested proteins in food and turnover of proteins in tissues and body fluids. Proteolysis of glycated proteins forms lower molecular mass glycated peptides and glycated amino acids. The latter are conveniently called glycation free adducts. Glycation free adducts are acutely sensitive to change in renal clearance in mammalian systems (Rabbani et al. 2007)_ Fig. 1c.

Glycation adduct residues of proteins have been called "protein-bound" glycation adducts-particularly for AGEs in renal failure research. This is discouraged as it is a misnomer; part of the glycation adduct structure is an integral part of the protein and hence binding of discrete glycation adduct is not involved. There may be noncovalent binding of discrete binding of glycation free adducts to plasma protein in some instances, particularly at the high levels of glycation free adducts found in renal failure (Agalou et al. 2005; Rabbani et al. 2007) and hence it is important to be able to distinguish between glycation adduct residues and binding of free adducts.

\section{Historical background of glycation}

In 1908, Arthur Robert Ling (1861-1937) produced flavoured and coloured compounds from thermal drying of proteins with sugars. He wrote "When these amino-compounds produced from proteins are heated at $120-140^{\circ} \mathrm{C}$ with sugars such as ordinary glucose or maltose, which are produced at this stage of process, combination occurs. The precise nature of the compounds produced is unknown to me, but they are probably glucosamine-like bodies" (Ling 1908). He also described the heating of glucose with asparagine producing browning pigments. These were amongst the earliest recorded adducts formed between glucose and an amino acid. In 1912, Maillard investigated the reaction between glucose and glycine on heating. He proposed that the brown pigmented product or melanoids involved an initial interaction between amines and saccharides forming Schiff's base adducts (Maillard 1912a). The non-enzymatic reaction of amino acids with sugars now bears his name, the "Maillard reaction". Maillard acknowledged the prior work of Ling in a later paper (Maillard 1912b). In 1913 the glyoxalase system that catalyses the conversion of $\mathrm{MG}$ to lactate and thereby suppresses dicarbonyl glycation in physiological systems was discovered (Dakin and Dudley 1913; Neuberg 1913). In 1925 and 1931, Mario Amadori demonstrated that the condensation of D-glucose with aromatic amines $p$-phenetidine, $p$-anisidine or $p$-toluidine gave two structurally different isomers which were not anomers (Amadori $1929 a, b)$. One of the isomers was more labile than the other towards hydrolysis and was also more susceptible to decomposition on standing in the solid state in air. He correctly recognised this as the $N$-glycosylamine but he mistakenly thought that the more stable isomer was a Schiff's base, overlooking its resistance to acid hydrolysis (Amadori 1929a). In 1936, Kuhn and Dansi found that the stable isomer was not a Schiff's base but rather the product of a molecular rearrangement. They also confirmed that the labile isomer was in fact the $N$-substituted glycosylamine (Kuhn and Dansi 1936). In 1937, Kuhn and Weygand reported the structure of the Amadori's stable isomer, which was the unbranched $N$-substituted 1-amino-1-deoxy2-ketose. Kuhn and Weygand later called the reaction the Amadori rearrangement involving generally aldoses and amines (Kuhn and Weygand 1937). In 1953, Hodge suggested that the Maillard reaction involved formation of a Schiff's base followed by Amadori rearrangement in the early stages. He also suggested that fructosamine degraded to glucosone and other adducts via enolisation, oxidation and fragmentation reactions (Hodge 1953). An excellent history of the early days of glycation research was given by Kawamura (1983).

In 1958, Allan et al. reported the first example of a glycated protein in vivo. They reported the presence of a negatively charged component of haemoglobin in human red blood cells (Allen et al. 1958). This was a variant of glycated haemoglobin $\mathrm{HbA}_{1}$. It was first characterized as a glycated haemoglobin by Bookchin and Gallop (1968), its increase in diabetes described by Rahbar (1968), reactions leading to its formation were characterized by Bunn and his co-workers (1975) and the use of the glucose adduct glycated haemoglobin $\mathrm{HbA}_{1 \mathrm{c}}$ for monitoring the glycemic control in diabetic patients was proposed by Anthony Cerami and coworkers (Koenig et al. 1976). Percentage of $\mathrm{HbA}_{1 \mathrm{c}}$ is now a routine clinical diagnostic measure of glycaemic control of diabetic patients worldwide.

In 1960, Anet reported the degradation of a fructosamine ( $N, N$-difructosylglycine) to 3-deoxyglucosone (Anet 1960). This was the first example of the importance of fructosamine dehydration to a 3-deoxy-2-oxoaldehyde. Kato also isolated 3-deoxyglucosone and 3-deoxypentosone from the browning reactions of glucose and ribose with an amine (Kato 1960; Kato et al. 1969, 1989). These reactive $\alpha$-oxoaldehyde products of the Maillard reaction are now seen as important precursors of glycation adduct formation in biological systems.

In 1973, Bonsignore et al. (1973) presented the first evidence that a triosephosphate, glyceraldehyde-3-phosphate, degraded non-enzymatically under physiological conditions to form MG. In 1977, Takahashi described the reaction of amino acids with glyoxal derivatives, including glyoxal and MG. Arginine was identified as the predominant amino acid modified and a hydroimidazolone was one molecular structure proposed for the adducts (Takahashi 
1977). Although no supporting analytical data were given, this was later to be confirmed as a major AGE in physiological systems and some foodstuffs (Ahmed et al. 2002; Henle et al. 1994; Thornalley et al. 2003).

In 1980, Nakayama et al. reported the formation of 6-(2-formyl-5-hydroxymethylpyrrol-1-yl)-L-norleucine from 3-deoxyglucosone and lysyl residues in proteins, now commonly known as pyrraline-an AGE (Nakayama et al. 1980). Hayashi and Namiki presented evidence for the fragmentation of the saccharide moiety early in the Maillard reaction, leading to the formation of $\alpha$-oxoaldehydes. Evidence for the formation of glyoxal and MG established saccharide fragmentation as a new series of reaction pathways in Maillard chemistry, now collectively called the Namiki pathway (Hayashi and Namiki 1980).

In 1984, a product formed from the degradation of Amadori product, 2-(2-furoyl)-4(5)-(2-furanyl)-1H-imidazole (FFI), was reported by Pongor et al. (1984). Wolff and co-workers reported the slow oxidative degradation of monosaccharides under physiological conditions to form the corresponding $\alpha$-oxoaldehyde and hydrogen peroxide. This process was called monosaccharide autoxidation (Wolff et al. 1984).

In 1986, Cerami first used the term advanced glycation endproducts (AGE) to refer to "brown fluorescent pigments which crosslink proteins" formed from the degradation of fructosamine (Cerami 1986). Brownlee et al. reported increased collagen cross-linking in the arterial walls of diabetic rats and associated fluorescence characteristic of AGE compounds. The nucleophilic hydrazine derivative, aminoguanidine (Pimagedine ${ }^{\mathrm{TM}}$ ), inhibited the formation of AGEs and diabetes-induced protein crosslinking (Brownlee et al. 1986). Ahmed et al. also reported the formation of $N \varepsilon$-carboxymethyl-lysine (CML) from the oxidative degradation of glycated proteins and also noticed that these two compounds were present in human urinary metabolite (Ahmed et al. 1986). CML was later found to be formed by the reaction of lysine residues with ascorbate and glyoxal formed in lipid peroxidation and is now one of the most studied AGEs in glycation research (Thorpe and Baynes 2002).

In 1988, Thornalley presented evidence linking hyperglycaemia in diabetes mellitus with increased flux of formation and concentration of MG (Thornalley 1988). Glycation by MG was later to be proposed as one of the key pathways driving the development of vascular complications of diabetes (Brownlee 2001).

In 1989, Monnier and Sell isolated an acid stable fluorescent compound from collagen_- "pentosidine". It was a crosslink formed from a pentose moiety with lysine and arginine residues and is a further highly studied AGE (Sell and Monnier 1989). In 1991, the enzymatic metabolism of fructosamine adducts was also discovered by Horiuchi and
Kurokawa-fructosyl-amino acid oxidase from bacteria catalysed the conversion of fructosyl-amino acids to the free amino acid, glucosone and hydrogen peroxide (Horiuchi and Kurokawa 1991).

In 1992, Schmidt and co-workers identified an AGE receptor protein from bovine lung endothelial cells-later shown to have a sequence mass of $42 \mathrm{kDa}$ (Schmidt et al. 1992). This was the receptor for advanced glycosylation endproducts (RAGE) and is the best characterised of the AGE receptors.

Over the period 1994-1998 the inhibitor of AGE formation Pimagedine ${ }^{\mathrm{TM}}$ was evaluated in clinical trials for the prevention of overt nephropathy in clinical diabetes (ACTION I and ACTION II). The trials were eventually terminated due to safety concerns and apparent lack of efficacy (Thornalley 2003c).

In 1996, Cerami and co-workers introduced the concept of "AGE breakers" - compounds that may cleave glycation derived crosslinks and reverse one of the damaging effects of glycation associated with ageing and disease. The prototype compound was $N$-phenacylthiazolium bromide (PTB; Vasan et al. 1996). Unfortunately this and related analogues had stability problems (Price et al. 2001; Thornalley and Minhas 1999).

In 1997, Shipanova et al. discovered argpyrimidine-a major fluorescence AGE formed from MG (Shipanova et al. 1997). Vlassara and co-workers used the term "glycotoxins" to refer to highly reactive AGE intermediates and initiated a series of on-going studies assessing the physiological effects of AGEs in the diet on health (Koschinsky et al. 1997).

In 2000, Delpierre et al. discovered fructosamine 3-kinase which catalyses the phosphorylation of fructosamine and fructosamine residues in proteins leading to the de-glycation and repair of early glycated proteins (Delpierre et al. 2000). A time-line diagram of glycation research development is given in Fig. 3.

In the last decade there has been a marked expansion of glycation-related research-particularly with application of proteomics to detection and quantitation of glycated proteins and glycation free adducts, cell signalling studies in response to RAGE and other response, functional genomics of components of enzymatic defence against glycation (fructosamine 3-kinase, glyoxalase 1 and aldoketo reductases), therapeutics development, food processing and other applications. The rate of scientific publication on glycation doubled in this time-Fig. 4.

\section{Importance of protein glycation}

In biology, protein glycation is implicated in the low level endogenous damage to the proteome with the ubiquitous 


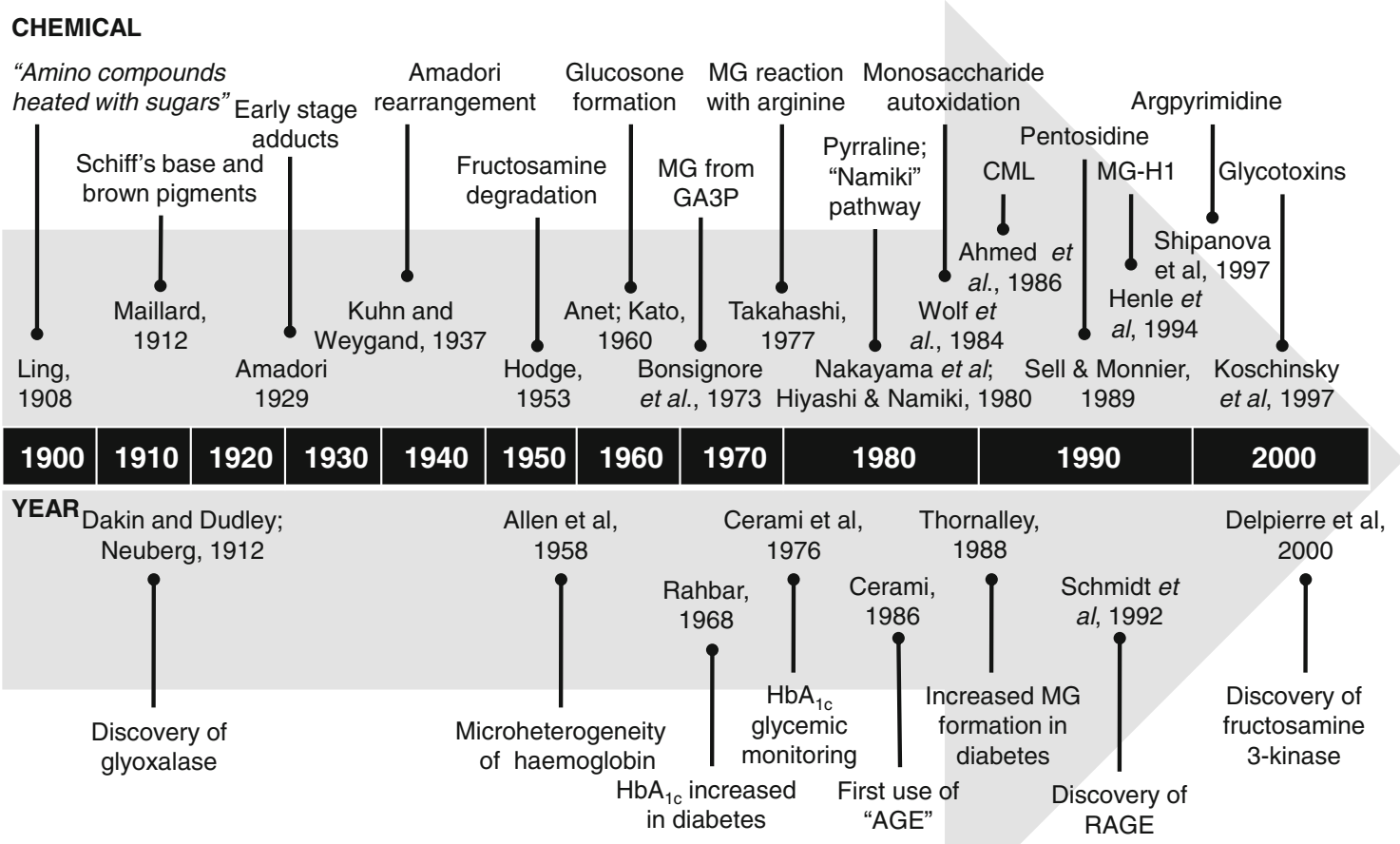

BIOMEDICAL

Fig. 3 Timeline showing key developments in glycation research from 1900 to 2000. GA3P glyceraldehyde-3-phosphate

Fig. 4 Publication frequency in glycation research over the period 1979-2009. The database used was ISI Web of knowledge and search terms were: glycation, glycated, nonenzymatic glycosylation, nonenzymic glycosylation and glucosylatyed. Total count: 18,928 . Inclusion of the terms glycohaemoglobin and glycosylated haemoglobin increased the count to 30,100 most papers relating to monitoring of glycemic control in diabetes

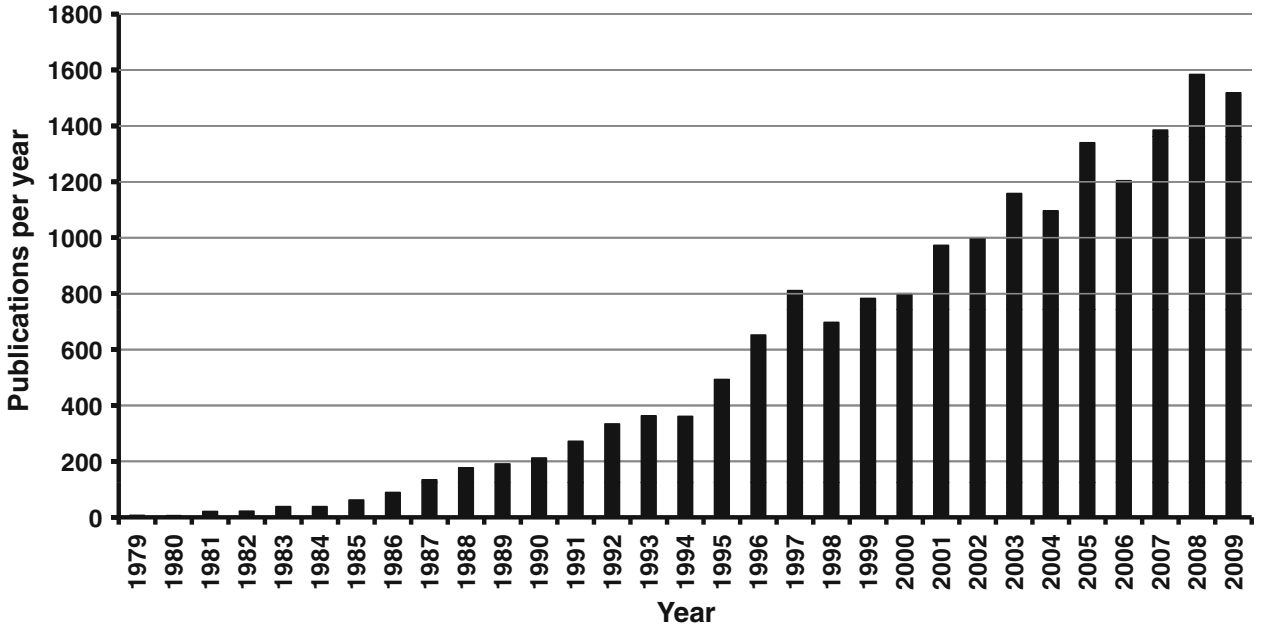

presence of an enzymatic defence akin to that of antioxidants to counter it. The enzymatic defence against glycation consists of enzymes that repair early glycated proteins and prevent glycation by metabolising dicarbonyl glycating agents: fructosamine 3-kinase (Delpierre et al. 2000), fructosamine 3-kinase-related protein (Delplanque et al. 2004) and others; and glyoxalase 1 (Thornalley 2003b) and aldoketo reductases 1A4, 1B1 and 1B3 (aldose reductase; Baba et al. 2009). The imbalance of glycating agents and enzymatic defence against glycation in favour of glycating agents has been termed carbonyl stress and is thought to contribute to ageing and disease (Miyata et al. 1999; Morcos et al. 2008; Xue et al. 2008). Emerging evidence of a chaperone function of lens crystallins (Gangadhariah et al. 2010) and a regulatory decrease in the enzymatic defence against glycation in inflammatory signalling (Thornalley 2007) is suggesting a beneficial functional role of protein glycation in some instances.

In the clinical setting, increased formation and steadystate accumulation of glycated proteins have been linked to disease development and progression-particularly diabetes and its vascular complications (Ahmed et al. 2005a; 
McCance et al. 1993), renal failure (Agalou et al. 2005; Miyata et al. 2001), cardiovascular disease and Alzheimer's disease (Ahmed et al. 2004a; Chen et al. 2004; Rabbani et al. 2010). Involvement in arthritis and cirrhosis (Ahmed et al. 2004b, 2006), mood affective disordersanxiety and Schizophrenia (Arai et al. 2010; Hambsch et al. 2010), Parkinson's disease (Kurz et al. 2010) and other disease is emerging.

In food and nutrition, glycation is increased in culinary processing - particularly during heating and alkaline-treated bakery products (Ahmed et al. 2005b; Henle 2001). Glycation may impair nutritional quality, influence intestinal microflora, post-prandial vascular dysfunction, glucose tolerance and obesity (Birlouez-Aragon et al. 2010; Tuohy et al. 2006). The contribution of glycation adducts in proteins in food to total physiological exposure to glycation adducts and pathological effect remains controversial (Henle 2007; Uribarri et al. 2010). Glycation adduct contents of food, pre-absorptive processing and metabolic transit of protein glycation adducts (bioavailability, clearance and residence time in the body) and functional effects remain critical issues for further investigation.

In pharmacology and toxicology, multidrug resistance associated with overexpression of glyoxalase 1 has suggested a role of dicarbonyl glycation in the mechanism of action of cytotoxic antitumour agents (Thornalley 2003a). Fortunately tumours with overexpression of glyoxalasenow known to be linked to Glol gene amplification (Santarius et al. 2010)_are sensitive to glyoxalase inhibitor therapy (Sakamoto et al. 2001; Thornalley et al. 1996). Drug development to increase dicarbonyl glycation by inhibition of glyoxalase 1 will likely find use in overcoming tumour multidrug resistance, and drug and dietary supplement development to decrease glycation will find use as disease therapeutics and prophylaxis for healthy ageing (Morcos et al. 2008).

Technological processing of medical products such as dialyse fluids for renal replacement therapy (Linden et al. 2002; Schalkwijk et al. 1999) and food and beverages such as sweetened cola drinks involve formation and exposure to dicarbonyl glycating agents (Lo et al. 2008). Formation of crosslinking in proteins for tanning and desired browning of skin in lotions also involves glycation (Avery and Bailey 2008; Petersen et al. 2004). Further development will optimise the levels of glycating agents and types and levels of glycation adducts for technological application.

\section{A forum to focus on glycation research}

Glycation research poses great challenges to scientists. The extent of glycation of proteins in physiological samples is typically low and the range of adducts diverse in physiological systems. In culinary-processed proteins the content of glycation adducts is high but they are often difficult to analyse intact and resistant to release without decomposition for analysis. Risk of formation of glycation adducts and some of their precursors during pre-analytic processing is nearly always significant and overestimation of analytes is often possible. The physiological effects of protein glycation are diverse, intricate and complex. Some longheld views on glycation hold good and some have been revised in recent years. To address these issues we seek to publish the best practise in experimental techniques, present experimental results from rigorous and imaginative testing of hypotheses, re-appraisal of old concepts and introduction of new ones, and discuss conflicting and confounding outcomes from all who involved in glycation research and beyond. This will be done in an environment of constructive expert peer review and supportive editorial management. The following articles are mainly collaborative efforts of expert and authoritative views on different areas of glycation research. They provide an excellent start.

We welcome the chance to publish your experimental reports, reviews and opinion on glycation research in future issues.

Acknowledgments We thank Professor Gert Lubec for embracing this initiative on glycation research and our colleagues who have given their time and efforts in support of it.

\section{References}

Agalou S, Ahmed N, Babaei-Jadidi R, Dawnay A, Thornalley PJ (2005) Profound mishandling of protein glycation degradation products in uremia and dialysis. J Am Soc Nephrol 16:1471-1485

Ahmed MU, Thorpe SR, Baynes JW (1986) Identification of $N \varepsilon-$ carboxymethyl-lysine as a degradation product of fructoselysine in glycated protein. J Biol Chem 261:4889-4894

Ahmed N, Argirov OK, Minhas HS, Cordeiro CA, Thornalley PJ (2002) Assay of advanced glycation endproducts (AGEs): surveying AGEs by chromatographic assay with derivatisation by aminoquinolyl- $N$-hydroxysuccimidyl-carbamate and application to $N \varepsilon$-carboxymethyl-lysine- and $N \varepsilon$-(1-carboxyethyl)lysinemodified albumin. Biochem J 364:1-14

Ahmed N, Ahmed U, Thornalley PJ, Hager K, Fleischer GA, Munch G (2004a) Protein glycation, oxidation and nitration marker residues and free adducts of cerebrospinal fluid in Alzheimer's disease and link to cognitive impairment. J Neurochem 92:255-263

Ahmed N, Thornalley PJ, Luthen R, Haussinger D, Sebekova K, Schinzel R, Voelker W, Heidland A (2004b) Processing of protein glycation, oxidation and nitrosation adducts in the liver and the effect of cirrhosis. J Hepatol 41:913-919

Ahmed N, Babaei-Jadidi R, Howell SK, Beisswenger PJ, Thornalley PJ (2005a) Degradation products of proteins damaged by glycation, oxidation and nitration in clinical type 1 diabetes. Diabetologia 48:1590-1603

Ahmed N, Mirshekar-Syahkal B, Kennish L, Karachalias N, BabaeiJadidi R, Thornalley PJ (2005b) Assay of advanced glycation 
endproducts in selected beverages and food by liquid chromatography with tandem mass spectrometric detection. Mol Nutr Food Res 49:691-699

Ahmed N, Ahmed U, Thornalley PJ, Watts R, Tarr J, Haigh R, Winyard P (2006) Profound increase in proteolytic products of glycated and oxidised proteins in synovial fluid and plasma in osteoarthritis and rheumatoid arthritis, corrected by TNF- $\alpha$ antibody therapy in rheumatoid arthritis. Rheumatology 45(Suppl 1):i53

Allen DW, Schroeder WA, Balog J (1958) Observations on the chromatographic heterogeneity of normal adult and fetal human hemoglobin: a study of the effects of crystallization and chromatography on the heterogeneity and isoleucine content. J Am Chem Soc 80:1628-1634

Amadori M (1929a) The condensation product of glucose and $p$-anisidine. Atti R Accad Naz Lincei 9:226-230

Amadori M (1929b) The product of the condensation of glucose and p-phenetidine. Atti R Accad Naz Lincei 9:68-73

Anet EFLJ (1960) Degradation of carbohydrates. I. Isolation of 3-deoxyhexosones. Aust J Chem 13:396-403

Arai M, Yuzawa H, Nohara I, Ohnishi T, Obata N, Iwayama Y, Haga S, Toyota T, Ujike H, Arai M, Ichikawa T, Nishida A, Tanaka Y, Furukawa A, Aikawa Y, Kuroda O, Niizato K, Izawa R, Nakamura K, Mori N, Matsuzawa D, Hashimoto K, Iyo M, Sora I, Matsushita M, Okazaki Y, Yoshikawa T, Miyata T, Itokawa M (2010) Enhanced carbonyl stress in a subpopulation of schizophrenia. Arch Gen Psychiatry 67:589-597

Avery N, Bailey A (2008) Restraining cross-links responsible for the mechanical properties of collagen fibers: natural and artificial. In: Fratzl P (ed) Collagen: structure and mechanics, pp 81-110

Baba SP, Barski OA, Ahmed Y, O'Toole TE, Conklin DJ, Bhatnagar A, Srivastava S (2009) Reductive metabolism of AGE precursors: a metabolic route for preventing AGE accumulation in cardiovascular tissue. Diabetes 58:2486-2497

Baynes JW (1991) Role of oxidative stress in the development of complications in diabetes. Diabetes 40:405-412

Baynes JW, Thorpe SR (2000) Glycoxidation and lipoxidation in atherogenesis. Free Radic Biol Med 28:1708-1716

Benedict SR (1909) A reagent for the detection of reducing sugars. J Biol Chem 5:485-487

Birlouez-Aragon I, Saavedra G, Tessier FJ, Galinier A, Ait-Ameur L, Lacoste F, Niamba CN, Alt N, Somoza V, Lecerf JM (2010) A diet based on high-heat-treated foods promotes risk factors for diabetes mellitus and cardiovascular diseases. Am J Clin Nutr 91:1220-1226

Bonsignore A, Leoncini G, Siri A, Ricci D (1973) Kinetic behaviour of glyceraldehyde 3-phosphate conversion into methylglyoxal. Ital J Biochem 22:131-140

Bookchin RM, Gallop PM (1968) Structure of hemoglobin $A_{1 c}$ : nature of the $N$-terminal $\beta$-chain blocking group. Biochem Biophys Res Commun 32:86-93

Brownlee M (2001) Biochemistry and molecular cell biology of diabetic complications. Nature 414:813-820

Brownlee M, Vlassara H, Kooney A, Ulrich P, Cerami A (1986) Aminoguanidine prevents diabetes-induced arterial wall protein cross-linking. Science 232:1629-1632

Bunn HF, Haney DN, Gabbay KH, Gallop PM (1975) Further identification of the nature and linkage of the carbohydrate in hemoglobin A1c. Biochem Biophys Res Commun 67:103-109

Cerami A (1986) Aging of proteins and nucleic acids: what is the role of glucose? TIBS 11:311-314

Chen F, Wollmer MA, Hoerndli F, Munch G, Kuhla B, Rogaev EI, Tsolaki M, Papassotiropoulos A, Gotz J (2004) Role for glyoxalase I in Alzheimer's disease. Proc Natl Acad Sci USA 101:7687-7692
Dakin HD, Dudley HW (1913) An enzyme concerned with the formation of hydroxy acids from ketonic aldehydes. J Biol Chem 14:155-157

Delpierre G, Rider MH, Collard F, Stroobant V, Vanstapel F, Santos $\mathrm{H}$, Van Schaftingen E (2000) Identification, cloning, and heterologous expression of a mammalian fructosamine-3-kinase. Diabetes 49:1627-1634

Delplanque J, Delpierre G, Opperdoes FR, Van Schaftingen E (2004) Tissue distribution and evolution of fructosamine 3-kinase and fructosamine 3-kinase-related protein. J Biol Chem 279:4660646613

Fu M-X, Requena JR, Jenkins AJ, Lyons TJ, Baynes JW, Thorpe SR (1996) The advanced glycation end product, $N^{\varepsilon}$-(carboxymethyl)lysine, is a product of both lipid peroxidation and glycoxidation reactions. J Biol Chem 271:9982-9986

Gangadhariah MH, Wang BL, Linetsky M, Henning C, Spanneberg R, Glomb MA, Nagaraj RH (2010) Hydroimidazolone modification of human alpha A-crystallin: effect on the chaperone function and protein refolding ability. Biochim Biophys Acta 1802:432-441

Hambsch B, Chen BG, Brenndorfer J, Meyer M, Avrabos C, Maccarrone G, Liu RH, Eder M, Turck CW, Landgraf R (2010) Methylglyoxal-mediated anxiolysis involves increased protein modification and elevated expression of glyoxalase 1 in the brain. J Neurochem 113:1240-1251

Hayashi T, Namiki M (1980) Formation of two-carbon sugar fragments at an early stage of the browning reaction of sugar and amine. Agric Biol Chem 44:2575-2580

Henle T (2001) A food chemist's view of advanced glycation endproducts. Perit Dial Int 21:S125-S130

Henle T (2007) Dietary advanced glycation end products-a risk to human health? A call for an interdisciplinary debate. Mol Nutr Food Res 51:1075-1078

Henle T, Walter A, HaeBner R, Klostermeryer H (1994) Detection and identification of a protein-bound imidazolone resulting from the reaction of arginine residues and methylglyoxal. Z Lebensm Unters Forsch 199:55-58

Hodge JE (1953) Dehydrated foods: chemistry of browning reactions in model systems. J Agric Food Chem 1:928-943

Hodge JE (1955) The Amadori rearrangement. Adv Carbohydr Chem 10:169-205

Horiuchi T, Kurokawa T (1991) Purification and properties of fructosylamine oxidase from Aspergillus sp. 1005. Agric Biol Chem 55:333-338

Kato H (1960) Studies on browning reactions between sugars and amino compounds. V. Isolation and characterisation of new carbonyl compounds, 3-deoxyglucosones formed from $\mathrm{N}$-glycosides and their significance for browning reaction. Bull Agric Chem Soc Jpn 24:1-12

Kato H, Yamamoto M, Fujimaki M (1969) Mechanisms of browning degradation of D-fructose in special comparison with D -glucoseglycine reaction. Agric Biol Chem 33:939-948

Kato H, Hayase F, Shin DB, Oimomi M, Baba S (1989) 3-Deoxyglucosone, an intermediate product of the Maillard reaction. In: The Maillard reaction in aging, diabetes and nutrition. Alan R. Liss, New York pp 69-84

Kawamura S (1983) 70 Years of the Maillard-reaction. ACS Symp Ser 215:3-18

Koenig RJ, Peterson CM, Jones RL, Saudek C, Lehrman M, Cerami A (1976) A correlation of glucose regulation and hemoglobin A1c in diabetes mellitus. N Engl J Med 295:417-420

Koschinsky T, He C-J, Mitsuhashi T, Bucala R, Liu C, Buenting C, Heitman K, Vlassara H (1997) Orally absorbed reactive glycation products (glycotoxins): an environmental risk factor in diabetic nephropathy. Proc Natl Acad Sci USA 94:6474-6479 
Kuhn R, Dansi A (1936) A molecular rearrangement of $N$-glucosides. Ber 69B:1745-1754

Kuhn R, Weygand F (1937) The Amadori rearrangement. Ber 70B:769-772

Kurz A, Rabbani N, Walter M, Bonin M, Thornalley PJ, Auburger G, Gispert S (2010) Alpha-synuclein deficiency leads to increased glyoxalase I expression and glycation stress. Cell Mol Life Sci (in press)

Linden T, Cohen A, Deppisch R, Kjellstrand P, Wieslander A (2002) 3, 4-Dideoxyglucosone-3-ene (3, 4-DGE): a cytotoxic glucose degradation product in fluids for peritoneal dialysis. Kidney Int 62:697-703

Ling AR (1908) Malting. J Inst Brew 14:521

Lis H, Sharon N (1993) Protein glycosylation-structural and functional-aspects. Eur J Biochem 218:1-27

Lo CY, Li S, Wang Y, Tan D, Pan MH, Sang S, Ho CT (2008) Reactive dicarbonyl compounds and 5-(hydroxymethyl)-2-furfural in carbonated beverages containing high fructose corn syrup. Food Chem 107:1099-1105

Maillard LC (1912a) Action des acides amines sur les sucres: formation des melanoidines par voie methodique. C R Hebd Seances Acad Sci 154:66-68

Maillard LC (1912b) Formation d'humus et de combustibles mineraux sans intervention de l'oxygene atmospherique des microorganismes, des hautes temperatures, ou des fortes pressions. C R Hebd Seances Acad Sci 155:1554-1556

McCance DR, Dyer DG, Dunn JA, Baiue KE, Thorpe SR, Baynes JW, Lyons TJ (1993) Maillard reaction products and their relation to complications in insulin-dependent diabetes mellitus. J Clin Invest 91:2470-2478

Miyata T, de Strihou C, Kurokawa H, Baynes JW (1999) Alterations in nonenzymatic biochemistry in uraemia: origin and significance of "carbonyl stress" in long-term uremic complications. Kidney Int 55:389-399

Miyata T, de Strihou C, Imasawa T, Yoshino A, Ueda Y, Ogura H, Kominami K, Onogi H, Inagi R, Nangaku M, Kurokawa K (2001) Glyoxalase I deficiency is associated with an unusual level of advanced glycation end products in a hemodialysis patient. Kidney Int 60:2351-2359

Morcos M, Du X, Pfisterer F, Hutter H, Sayed AAR, Thornalley P, Ahmed N, Baynes J, Thorpe S, Kukudov G, Schlotterer A, Bozorgmehr F, El Baki RA, Stern D, Moehrlen F, Ibrahim Y, Oikonomou D, Hamann A, Becker C, Zeier M, Schwenger V, Miftari N, Humpert P, Hammes HP, Buechler M, Bierhaus A, Brownlee M, Nawroth PP (2008) Glyoxalase-1 prevents mitochondrial protein modification and enhances lifespan in Caenorhabditis elegans. Aging Cell 7:260-269

Nakayama T, Hayase F, Kato H (1980) Formation of $N_{\varepsilon}$-(2-formyl-5hydroxy-methyl-pyrrol-1-yl)-L- norleucine in the Maillard reaction between D-glucose and L-lysine. Agric Biol Chem 44:1201-1202

Neuberg C (1913) The destruction of lactic aldehyde and methylglyoxal by animal organs. Biochem Z 49:502-506

Petersen AB, Wulf HC, Gniadecki R, Gajkowska B (2004) Dihydroxyacetone, the active browning ingredient in sunless tanning lotions, induces DNA damage, cell-cycle block and apoptosis in cultured HaCaT keratinocytes. Mutat Res 560:173-186

Pongor S, Ulrich PC, Benesath FA, Cerami A (1984) Aging of protiens: isolation and identification of a fluorescent chromophore from the reaction of polypeptides with glucose. Proc Natl Acad Sci USA 81:2684-2688

Price DL, Rhett PM, Thorpe SR, Baynes JW (2001) Chelating activity of advanced glycation end-product inhibitors. J Biol Chem 276:48967-48972

Rabbani N, Sebekova K, Sebekova K Jr, Heidland A, Thornalley PJ (2007) Protein glycation, oxidation and nitration free adduct accumulation after bilateral nephrectomy and ureteral ligation. Kidney Int 72:1113-1121

Rabbani N, Varma Chittari M, Bodmer CW, Zehnder D, Ceriello A, Thornalley PJ (2010) Increased glycation and oxidative damage to apolipoprotein B100 of LDL in patients with type 2 diabetes and effect of metformin. Diabetes 59:1038-1045

Rahbar S (1968) An abnormal hemoglobin in red cells of diabetics. Clin Chim Acta 22:296-298

Sakamoto H, Mashima T, Sato S, Hashimoto Y, Yamori T, Tsuruo T (2001) Selective activation of apoptosis program by S- $p$ bromobenzylglutathione cyclopentyl diester in glyoxalase I-overexpressing human lung cancer cells. Clin Cancer Res 7:2513-2518

Santarius T, Bignell GR, Greenan CD, Widaa S, Chen L, Mahoney CL, Butler A, Edkins S, Waris S, Thornalley PJ, Futreal PA, Stratton MR (2010) GLO1-a novel amplified gene in human cancer. Genes Chromsomes Cancer 49:711-725

Schalkwijk CG, Posthuma N, ten Brink HJ, ter Wee PM, Teerlink T (1999) Induction of 1, 2-dicarbonyl compounds, intermediates in the formation of advanced glycation end-products, during heatsterilization of glucose-based peritoneal dialysis fluids. Perit Dialysis Int 19:325-333

Schmidt A-M, Vianna M, Gerlach M, Brett J, Ryan J, Kao J, Esposito C, Hegarty H, Hurley W, Clauss M, Wang F, Pan YE, Tsang TE, Stern D (1992) Isolation and characterization of two binding proteins for advanced glycosylation endproducts from bovine lung which are present on the endothelial cell surface. J Biol Chem 267:14987-14997

Sell DR, Monnier VM (1989) Structure elucidation of a senescence crosslink from human extracellular matrix. Implication of pentoses in the aging process. J Biol Chem 264:21597-21602

Sharon N (1986) IUPAC-IUB joint commission on biochemical nomenclature (Jcbn) - nomenclature of glycoproteins, glycopeptides and peptidoglycans-Jcbn recommendations 1985. Glycoconj J 3:123-134

Shipanova IN, Glomb MA, Nagaraj RH (1997) Protein modification by methylglyoxal: chemical nature and synthetic mechanism of a major fluorescent adduct. Arch Biochem Biophys 344:29-36

Takahashi K (1977) Further studies on the reactions of phenylglyoxal and related reagents with proteins. Biochem J 81:403-414

Thornalley PJ (1988) Modification of the glyoxalase system in human red blood cells by glucose in vitro. Biochem J 254:751-755

Thornalley PJ (2003a) Protecting the genome: defence against nucleotide glycation and emerging role of glyoxalase I over expression in multidrug resistance in cancer chemotherapy. Biochem Soc Trans 31:1372-1377

Thornalley PJ (2003b) The enzymatic defence against glycation in health, disease and therapeutics: a symposium to examine the concept. Biochem Soc Trans 31:1343-1348

Thornalley PJ (2003c) Use of aminoguanidine (Pimagedine) to prevent the formation of advanced glycation endproducts. Arch Biochem Biophys 419:31-40

Thornalley PJ (2007) Dietary AGEs and ALEs and risk to human health by their interaction with the receptor for advanced glycation endproducts (RAGE) — an introduction. Mol Nutr Food Res 51:1107-1110

Thornalley PJ, Minhas HS (1999) Rapid hydrolysis and slow $\alpha, \beta$ dicarbonyl cleavage of an agent proposed to cleave glucosederived protein cross-links. Biochem Pharmacol 57:303-307

Thornalley PJ, Edwards LG, Kang Y, Wyatt C, Davies N, Ladan MJ, Double J (1996) Antitumour activity of $S$-p-bromobenzylglutathione cyclopentyl diester in vitro and in vivo. Inhibition of glyoxalase I and induction of apoptosis. Biochem Pharmacol 51:1365-1372

Thornalley PJ, Battah S, Ahmed N, Karachalias N, Agalou S, BabaeiJadidi R, Dawnay A (2003) Quantitative screening of advanced 
glycation endproducts in cellular and extracellular proteins by tandem mass spectrometry. Biochem J 375:581-592

Tuohy KM, Hinton DJS, Davies SJ, Crabbe MJC, Gibson GR, Ames JM (2006) Metabolism of Maillard reaction products by the human gut microbiota-implications for health. Mol Nutr Food Res 50:847-857

Uribarri J, Woodruff S, Goodman S, Cai WJ, Chen X, Pyzik R, Yong A, Striker GE, Vlassara H (2010) Advanced glycation end products in foods and a practical guide to their reduction in the diet. J Am Diet Assoc 110:911-916

Vasan S, Zhang X, Kapurniotu A, Bernhagen J, Teichberg S, Basgen J, Wagle D, Shih D, Terlecky I, Bucala R, Cerami A, Egan J, Ulrich P (1996) An agent cleaving glucose-derived protein crosslinks in vitro and in vivo. Nature 382:275-278
Wolff SP, Crabbe MJC, Thornalley PJ (1984) The autoxidation of $\alpha$-hydroxyketones. Experientia 40:244-246

Xue M, AntonySunil A, Rabbani N, Thornalley PJ (2008) Protein damage by glycation, oxidation and nitration in the ageing process. Advances in quantitation of protein damage and the emerging importance of decline in enzymatic defences as the ageing phenotype develops. In: Foyer $\mathrm{CH}$, Faraghar R, Thornalley PJ (eds) Redox metabolism and longevity relationships in animals and plants. Garland Science, London, pp 227-265

Thorpe SR, Baynes JW (2002) CML: a brief history. In: Maillard reaction in food chemistry and medical science: update for the postgenomic era, vol 1245, pp 91-99 